\title{
ПСИХОЛОГО-ПЕДАГОГІЧНІ ЗАСАДИ ФОРМУВАННЯ ЕКОЛОГІЧНОЇ КУЛЬТУРИ СТУДЕНТІВ
}

\section{О. В. Літвінова, О. І. Беспарточна}

Кременчуцький національний університет імені Михайла Остроградського,

вул. Першотравнева, 20, м. Кременчук, 39614, Україна. E-mail: litvinova1992@ gmail.com

Обгрунтовано теоретичні основи дослідження проблеми формування екологічної культури студентів в процесі навчання у вузі. Доведено актуальність вивчення даної проблеми в умовах глобальної екологічної кризи i потреби знаходження ефективних засобів формування екологічної культури особистості. Проаналізовано теоретико-методологічні підходи до вивчення категорії «екологічна культура» в сучасній науці та психологопедагогічних засад iï формування. Проведено емпіричне дослідження наявного рівню розвитку когнітивного, емоційно-оцінного та поведінкового компонентів екологічної культури студентів. Визначено, що половина опитаних респондентів має фрагментарне, недостатньо усвідомлене уявлення про екологічну культуру, проявляє зневажливе ставлення до природних ресурсів, не готові проявляти екологічно спрямовану поведінку. Для таких студентів характерним $є$ низький рівень екологічних та моральних цінностей, в структурі екоціннісних диспозицій переважають індивідуально-орієнтовані цінності. Наголошено на необхідності створення психолого-педагогічних умов формування екологічної культури студентів на основі впровадження в систему їх підготовки екологічної складової навчальних дисциплін, а також спеціально організованого еколого-орієнтованого тренінгу.

Ключові слова: екологічна культура, цінності, екологічна свідомість, студентський вік, екоціннісні диспозиції, екологічно-орієнтований тренінг.

\section{ПСИХОЛОГО-ПЕДАГОГИЧЕСКИЕ ОСНОВЫ ФОРМИРОВАНИЯ ЭКОЛОГИЧЕСКОЙ КУЛЬТУРЫ СТУДЕНТОВ}

\section{О. В. Литвинова, Е. И. Беспарточная}

Кременчугский национальный университет имени Михаила Остроградского

ул. Первомайская, 20. г. Кременчуг, 39614, Украина. E-mail: litvinova1992@gmail.com

Обоснованы теоретические основы исследования проблемы формирования экологической культуры студентов во время обучения в вузе. Сделан акцент на актуальности исследования данной проблемы, что обусловлено глобальным экологическим кризисом, а также необходимостью нахождения эффективных методов формирования экологической культуры личности. Проанализированы теоретико-методологические подходы к изучению категории «экологическая культура» в современной науке и психолого-педагогические основы ее формирования. Представлены результаты эмпирического исследования уровня развития когнитивного, эмоциональнооценочного и поведенческого компонентов экологической культуры студентов. Представления студентов об экологической культуре фрагментарные, отсутствует осознание ценности природных ресурсов, готовность проявлять экологически целесообразное поведение на недостаточном уровне. Для респондентов с такими проявлениями характерным является низкий уровень развития экологических и моральных ценностей, в структуре экоценностных диспозиций преобладают индивидуально-ориентированные ценности. Сделан акцент на необходимости создания психолого-педагогических условий для формирования экологической культуры студентов на основе внедрения в систему их подготовки экологической составляющей в учебных дисциплинах, а также проведение специально организованного экологично ориентированного тренинга.

Ключевые слова: экологическая культура, ценности, экологическое сознание, студенческий возраст, экоценностные диспозиции, экологически ориентированный тренинг.

АКТУАЛЬНІСТЬ РОБОТИ. Екологічна криза, яка сьогодні стала реальністю, ставить на порядок денний проблему кардинальних змін в екологічний культурі та у способі життя як окремих особистостей, так і спільнот взагалі. Конструктивне вирішення проблеми ліквідації глобальної екологічної кризи неможливе поза рамками екологічної культури, яка виступає необхідною передумовою оптимізації взаємовідносин суспільства та природи. Екологічна культура - це такий напрям людській діяльності та мислення, від якого істотним чином залежить нормальне існування сучасної цивілізації, іiі сталий розвиток у майбутньому. Екологічна культура має давню історію, вона $є$ атрибутивною, тобто органічною складовою людського життя 3 часів його виникнення. Водночас вона - феномен XXI століття, коли людство дедалі більше усвідомлює необхідність перетворення свого життя, 3 тим щоб вона стало безпечним, здоровим, радісним, щоб екологічна ку- льтура кожного зокрема і всіх разом стала імперативом буття.

Одним 3 найважливіших компонентів екологічної політики кожної держави є підготовка спеціалістів, здатних вирішувати екологічні завдання різного масштабу. Зміст екологічної освіти можна висловити у вигляді трьох взаємопов'язаних компонентів: знання екологічних законів, правил, теорій, понять, наукових факторів; практична діяльність в реальних ситуаціях, пов'язана з вирішенням екологічних проблем; емоційно-естетичне сприйняття природи та ставлення людини до неї. Знання про довкілля, розуміння різних видів взаємозв'язків, які виникають між людиною та навколишнім середовищем $є$ необхідною умовою взаємного узгодження економічних, екологічних, соціально-психологічних чинників сталого розвитку. Введення в освітні програми вищої освіти дисциплін чи тематики лекційних і практичних занять, враховуючи їх екологічну спрямова- 
ність, застосування активних методів в навчальному процесі має сприяти підвищенню екологічної грамотності, формуванню в студентів екологічного світогляду, екологічного мислення й екологічної культури. Це все покликано заповнити недолік у загальній фундаментальній природничонауковій освіті, навчити застосовувати набуті екологічні знання у своїй майбутній професійній діяльності.

Проблема вивчення екологічної культури $є$ міждисциплінарною, вона представлена у межах філософії, соціології, екології, педагогіки та психології. Дослідження екологічної культури та форм її реалізації - екологічна свідомість і діяльність представлені у роботах В. Борейко, О. Верніка, В. Васютинського, С. Дерябо, І. Кряж, А. Льовочкіної, В. Скребця, Ю. Швалба, В. Ясвіна та багатьох інших.

Культура в цілому, за своєю суттю, має екологічний характер, екологічна ж культура може бути визначена як певна програма, опредмечена в діяльності, на основі якої суб'єкт природокористування будує свій історично-конкретний процес взаємодії з природою. М. Ф. Тарасенко інтерпретує екологічну культуру як своєрідний світогляд «образу світу», в якому відображено такий стан соціально-природних залежностей, який характеризує їх гармонійну єдність, раціональне освоєння людиною природної та соціальної дійсності і утвердження в цьому процесі своєї власної індивідуальної самобутності [1].

Екологічна культура - це тип життєдіяльності людини, що успадковується, та її взаємовідносини з навколишнім середовищем, що сприяють здоровому способові життя, стійкому соціально-економічному розвитку, екологічній безпеці країни і кожної людини. Вона $є$ засобом самоорганізації сутнісних сил людини в умовах конкретного природного середовища.

Українські вчені, досліджуючи екологічну культури особистості визначали їі як: 1) цілепокладаючу діяльність людини (включаючи наслідки такої діяльності), спрямовану на організацію та трансформацію природного світу (об'єктів та процесів) відповідно до власних потреб та намірів (В. С. Крисачено); 2) систему індивідуальних морально-етичних норм, поглядів, установок, цілей і цінностей, що стосуються взаємовідносин у системі «людина-довкілля» і реалізується через екологічну свідомість, які відображає мікрорівень, мезорівень, макрорівень та мегарівень середовища, а також через екологічну діяльність, що проявляється у підтримці, розвитку довкілля та у створенні його елементів (А. Льовочкіна).

С. Д. Дерябо, В. А. Ясвін, О. М. Захлєбний вважають, що необхідно формувати в студентів екоцентричний світогляд, знання й уміння дослідницького характеру; сприяти переходові засвоєних знань i моральних принципів поведінки в навколишньому середовищі в особисті переконання; залучати студентів у практичну діяльність для вирішення проблем навколишнього середовища місцевого значення [2; $3 ; 4]$.

Мета статті - визначити і охарактеризувати психолого-педагогічні засади формування екологічної культури студентів.
МАТЕРІАЛ І РЕЗУЛЬТАТИ ДОСЛІДЖЕНЬ. Екологічна культура, за своїм змістом, є сукупністю знань, норм, стереотипів та правил поведінки людини в оточуючому її природному світі. I хоча феномен екологічної культури є надбанням XX століття, про екологічну компоненту культури можна твердити від самих початків появи людини. Ця компонента проявлялась як сукупність певних екокультурних норм, «заборон» та «дозволів» [5].

Екологічну культуру розглядають як багатомірний цілісний компонент інтелектуальної та духовної культури особистості, як суб'єктний, системний досвід особистості, що забезпечує ії творчу самореалізацію у вирішенні екологічних проблем. Як зазначають І. Симонова та О. Варнікова [6], екологічна культура студентів формується тільки в інтеграції трьох напрямків: екологічної свідомості, екологічної поведінки та екологічної освіти. Тільки при суміщенні та розвитку всіх трьох компонентів можливе формування цілісної, екологічно культурної та гармонійно розвинутої особистості студента.

Отже, головною специфічною рисою екологічної культури є те, що вона не утворюється стихійно, а виникає шляхом формування умов, що сприяють розгортанню iii принципів та спеціальним видом діяльності - екологічним вихованням. Від рівня екологічної культури людства, в першу чергу молоді, якій належить майбутнє, залежить вирішення проблеми глобальної екологічної кризи, збереження природних умов існування цивілізації.

Основний методологічний принцип екологічної педагогіки, на думку провідних дослідників з екопсихології С. Дерябо і В. Ясвін, полягає в чіткій відповідальності педагогічного процесу екологічного виховання психологічному процесу формування екологічної свідомості [7]. Отже, цей принцип означає, що для ефективності педагогічного процесу, який формує екологічну свідомість особистості, необхідно задіяти в ньому якомога більше різноманітних психологічних факторів та механізмів, які сприяють формуванню екоцентричного типу екологічної свідомості.

Цілеспрямовану педагогічну діяльність по формуванню екологічної культури студентів в період навчання у вузі можна розглядати як один 3 найкращих періодів такої діяльності завдяки тому, що просторо-часові фактори для цього періоду розвитку особистості складаються найкращим чином, оскільки [8]:

- студентський вік є найбільш сенситивним для розвитку рефлексивних здібностей, осмислення себе в світі та світу навколо себе;

- відбувається професійне становлення особистості, яке можливо спрямувати на формування екоорієнтованих технологій виробничої діяльності;

- освітнє середовище вищих закладів освіти в змозі забезпечити морально-розвиваючу атмосферу прийняття екологічних цінностей, де можлива організація необхідного спілкування 3 носіями екологічної культури і де в повному обсязі можна здійснити екологічну освіту;

- можна забезпечити безперервний процес формування екологічної культури студенів, починаючи 
від загальної екоорієнтованої культури до стилю життя.

Формування екологічної культури студентської молоді може відбуватися за рахунок внесення у дисципліни соціально-гуманітарної складової навчального плану екологічно-спрямованої тематики, застосування на практичних заняттях 3 дисциплін даного напряму інтерактивних засобів навчання, завдяки чому буде відбуватися активне засвоєння необхідних знань, їхе активне обговорення, а також відпрацювання навичок екологічно-орієнтованої поведінки.

Запропоновані зміни у змісті навчання дисциплін полягають в оновленні змісту навчальних програм завдяки їх доповненню й збагаченню теоретичними положеннями щодо сутності екологічної культури, iї ролі в сучасному суспільстві та в майбутній професійній діяльності, акцентування на значущості кожної $з$ дисциплін для досягнення успіху в ії здійснені.

Для формування екологічної культури доцільно застосувати екологічно орієнтований тренінг (ЕОТ), в основі якого лежить принцип поетапності розвитку групи і поступовості в більш глибокому розумінні кожним учасником себе як частини природи [9]. Такий тренінг представляє собою комплексну форму екологічної освіти, що грунтується на методології соціально-психологічного тренінгу, яка спрямована на формування екологічної культури особистості. ЕОТ передбачає вирішення наступних завдань: корекція, формування і розвиток екологічної культури особистості; подолання антропоцентричного, прагматичного ставлення до природних об'єктів; корекція мети взаємодії особистості з природними об'єктами; навчання умінням і навичкам такої взаємодії; розвиток перцептивних можливостей суб'єкта під час його контактів з природними об'єктами; розширення індивідуального екологічного простору.

В рамках дослідження було проведено психолого-педагогічний експеримент за допомогою авторської анкети «Моє розуміння екологічної культури особистості» і методики «Екоціннісні диспозиції» українського екологічного психолога В.О. Скребця [10]. В дослідженні взяли участь студенти, які навчаються на спеціальностях гуманітарної спрямованості у кількості 60 осіб.

За допомогою анкетування було виявлено особливості розвитку когнітивного, емоційно-оцінного та поведінкового компонентів екологічної культури студентів. 3'ясовано, що 37,5 \% студентів взагалі не розуміють, що таке «екологічна культура», що викликає велике занепокоєння. 62,5 \% студентів дали свою відповідь, розуміючи під ним: «дбайливе ставлення до природних ресурсів», «напрям людської діяльності, від якої залежить наша цивілізація», «культура людей на природі та їхнє розуміння про забрудненість навколишнього середовища», «правила для збереження середовища», «розуміння важливості екології в житті людини», «це те, що людина робить для чистоти природи» та ін. Отже, визначення категорії екологічна культура є для деяких студентів розмитим, фрагментарним, а для третини взагалі незрозумілим.
Далі проаналізуємо відповіді студентів на інші питання когнітивної складової екологічної культури (табл. 1).

Таблиця 1 - Результати анкетування за питаннями анкети першого блоку (когнітивна складова)

\begin{tabular}{|c|c|}
\hline Відповіді & $\%$ \\
\hline \multicolumn{2}{|l|}{$\begin{array}{c}\text { «Чи иүікавитесь Ви подіями, } \\
\text { що відбуваються в сфері екологї̈?? }\end{array}$} \\
\hline Так & 66,7 \\
\hline $\mathrm{Hi}$ & 33,3 \\
\hline \multicolumn{2}{|l|}{$\begin{array}{c}\text { «Які екологічні проблеми викликають } \\
\text { у Вас найбільшу занепокоєність»? }\end{array}$} \\
\hline Вирубка лісів & 25 \\
\hline Забруднення водних об’єктів & 50 \\
\hline Забруднення повітря & 37,5 \\
\hline $\begin{array}{l}\text { Відсутність культури поведінки людей на } \\
\text { природі }\end{array}$ & 50 \\
\hline $\begin{array}{l}\text { Відсутність екологічної освіти та вихован- } \\
\text { ня в закладах освіти }\end{array}$ & - \\
\hline \multicolumn{2}{|c|}{$\begin{array}{l}\text { "Чи залежить розвиток особистості від перспе- } \\
\text { ктив взаємодї̈ між суспільством і природою»? }\end{array}$} \\
\hline Так, залежить & 66,7 \\
\hline Нi, не залежить & 12,5 \\
\hline Не знаю & 20,8 \\
\hline
\end{tabular}

Аналізуючи відповіді на дані питання зазначимо, що більшість студентів, все ж таки, цікавляться проблемою збереження природи, особливо їх занепокоять питання щодо забруднення водних об'єктів (що можна пояснити проживанням в місцевості, де існує велика кількість водних об'єктів - річки Дніпро, Псьол, Кагамлик, Кременчуцьке водосховище і вони вочевидь мають змогу відчувати наслідки забруднення - це і затхлий запах влітку, і цвітіння Дніпра, i зменшення кількості риби та ін.). Також студентів турбує відсутність культури поведінки людей на природі, але це тільки 50 \% респондентів, і тому це доводить, що саме ця половина опитаних не залишає сміття, прибираючи за собою, а можливо і можуть звернути увагу інших відпочиваючих на необхідність прибрати за собою сміття, адже природа не може переробити всі залишки людської діяльності і страждає з-за цього.

У своєрідному вступі до проблеми «людина природа», зробленому при аналізі екологопізнавальних інтересів молоді, був відзначений такий момент, на запитання «Як ви думаєте, чи залежить розвиток особистості від перспектив взаємодії між суспільством і природою?» $66,7 \%$ опитаних відповіли ствердно: «так, залежить», 12,5 \% - «ні, не залежить», 20,8 \% - утруднилися відповісти. Неможливість студентів-гуманітаріїв розуміти взаємозв'язки між соціальним впливом та розвитком особистості становить питання відкритим, тому цей фактор наголошує на необхідності створення потужних психолого-педагогічних технологій щодо розвитку екологічної культури особистості, адже нерозуміння цього фактору сьогодні молодими людьми, потенційними батьками ставить загрозу для подальшого екологічного виховання майбутніх поколінь.

В анкеті було надано блок питань, які стосува- 
лись бачення студентів розвитку екологічного виховання в стінах університету і взагалі їхнього розуміння того, хто повинен це робити, що також відноситься до когнітивної складової екологічної культури (табл. 2).

Таблиця 2 - Результати анкетування за питаннями анкети другого блоку (когнітивна складова)

\begin{tabular}{|c|c|}
\hline Відповіді & $\%$ \\
\hline \multicolumn{2}{|c|}{$\begin{array}{c}\text { «Хто повинен виховувати екологічну культуру } \\
\text { особистості»? }\end{array}$} \\
\hline Сім'я & 54,2 \\
\hline Школа, університет & 20,8 \\
\hline $\begin{array}{l}\text { Людина сама повинна набувати певного } \\
\text { рівню культури }\end{array}$ & 50 \\
\hline Засоби масової інформації & 16,7 \\
\hline \multicolumn{2}{|l|}{ «Для чого потрібна екологічна обізнаність»? } \\
\hline $\begin{array}{l}\text { Щоб самостійно розібратися в екологічно- } \\
\text { му стані навколишнього середовища }\end{array}$ & 41,7 \\
\hline Це умова здорового способу життя & 45,5 \\
\hline $\begin{array}{l}\text { Щоб піклуватися про природу для майбут- } \\
\text { ніх поколінь }\end{array}$ & 37,5 \\
\hline \multicolumn{2}{|c|}{$\begin{array}{c}\text { «Яка увага, на ваш погляд, приділяється } \\
\text { питанням охорони природи та раціонального } \\
\text { використання ресурсів в стінах університеті»? }\end{array}$} \\
\hline Приділяють значну увагу & 16,7 \\
\hline Мало уваги & 37,5 \\
\hline Взагалі не приділяють & 4,2 \\
\hline Не можу відповісти & 41,6 \\
\hline \multicolumn{2}{|l|}{$\begin{array}{c}\text { «Чи вважаєте Ви за необхідне підвищувати } \\
\text { рівень своєї екологічної культури? }\end{array}$} \\
\hline Так, вважаю & 54,2 \\
\hline Нi, не вважаю & 29,2 \\
\hline Не знаю & 16,3 \\
\hline
\end{tabular}

Вищезазначений блок питань бав змогу зрозуміти те, на кого покладають відповідальність студенти щодо розвитку екологічної культури, як оцінюють свій рівень іiі розвитку. Більшість відсотків студентів вважають відповідальною сім'ю за створення фундаменту екологічної культури (54,2 \%), $50 \%$ вважать, що людина повинна і сама брати відповідальність за самовиховання, тільки 20 \% вважать, що інші інститути соціалізації (школа та університет) повинні також створювати умову для екологічної просвіти. Цікаво, що 37,2 \% студентів при цьому вважають, що в університеті мало уваги приділяють цьому питанню, а 41,6 \% взагалі не могли відповісти на це питання (або взагалі не цікавляться, або не приймають участь в поза аудиторних заходах, або дійсно, дисципліни, що викладаються не мають екологічної компоненти). Однак при цьому, 54,2 \% студентів вважають за необхідне підвищувати свою екологічну культуру, адже це створює умови для здорового способу життя (45,5\%), підвищує рівень обізнаності (41,7 \%) і закладає основу для майбутніх поколінь (37,5\%). Тобто знов бачимо, що з одного боку є студенти, які розуміють необхідність створення умов для розвитку екологічної культури, розуміють іiі важливість, відслідковують екологічноорієнтовані заходи, що відбуваються в університеті, а $з$ іншого боку - $є$ студенти, які проявляють пасив- ність, байдужість до цього важливого питання, хоча і розуміють важливість екологічної культури.

Анкета містила питання стосовно емоційнооцінного компоненту, а саме: «Чи турбує Вас стан навколишнього середовища»?, стосовно якого відповіді розподілились наступним чином: 33,3 відповіли «викликає велику стурбованість», «в якійсь мірі турбує» - 58,3 \%; «не турбує» - 8,4 \% респондентів. Ця відповідь корелює з попередніми висновками і дозволяє стверджувати, що на екологічну культуру особистості впливає багато факторів, а особливо культура виховання в родині, риси характеру, ціннісні орієнтації тощо.

Третій блок питань анкети було присвячено питанням, які дали можливість від слідкувати поведінковий компонент екологічної культури, тобто готовність студентів-психологів до конкретних проявів у власній поведінці (табл. 3).

Таблиця 3 - Результати анкетування за питаннями анкети третього блоку (поведінкова складова)

\begin{tabular}{|c|c|}
\hline Відповіді & $\%$ \\
\hline \multicolumn{2}{|c|}{$\begin{array}{l}\text { «К, на Вашу думку, можна підвищити рівень } \\
\text { екологічно культури особистості»? }\end{array}$} \\
\hline $\begin{array}{l}\text { Проводити екологічні акції по вбиранню } \\
\text { території від сміття }\end{array}$ & 41,7 \\
\hline $\begin{array}{l}\text { Розповсюджувати просвітницькі буклети } \\
\text { щодо наслідків некорисного використання } \\
\text { природних ресурсів }\end{array}$ & 41,7 \\
\hline $\begin{array}{l}\text { Проводити лекції, семінари, круглі столи } \\
\text { щодо обговорення екологічного стану нашо- } \\
\text { го регіону }\end{array}$ & 33,3 \\
\hline \multicolumn{2}{|c|}{$\begin{array}{c}\text { «Як ви вважаєте, щ⿻ конкретно кожна людина } \\
\text { може зробити для збереження природи»? }\end{array}$} \\
\hline $\begin{array}{l}\text { Нічого не може, вплив технічних засобів } \\
\text { занадто погано впливає на природу і ніякого } \\
\text { толку від зусиль однієї людини не буде }\end{array}$ & 4,2 \\
\hline $\begin{array}{l}\text { Людина може менше шкодити навколиш- } \\
\text { ньому середовищу, але зробити її краще вже } \\
\text { не в змозі }\end{array}$ & 20,1 \\
\hline $\begin{array}{l}\text { Від кожної людини залежить багато чого, } \\
\text { усі можуть і повинні не тільки не робити } \\
\text { шкоду природі, але й можливим зусиллями } \\
\text { турбуватися про її покращення }\end{array}$ & 75,7 \\
\hline \multicolumn{2}{|l|}{$\begin{array}{c}\text { «Що особисто Ви готові зробити для того, } \\
\text { щчоб покращчити екологічну ситуацію»? }\end{array}$} \\
\hline $\begin{array}{l}\text { Зменшити використання продуктів, що ви- } \\
\text { кликають забруднення навколишнього сере- } \\
\text { довища (пластик, поліетиленова упаковка та } \\
\text { ін.) }\end{array}$ & 25 \\
\hline $\begin{array}{l}\text { Брати участь в акціях по вбиранню території } \\
\text { та інших заходах }\end{array}$ & 20,8 \\
\hline Займатись роздільним збором сміття & 37,5 \\
\hline $\begin{array}{l}\text { Проводити агітацію серед населення } 3 \text { при- } \\
\text { воду дбайливого ставлення до природи }\end{array}$ & 12 \\
\hline $\begin{array}{l}\text { Підвищувати рівень своїх екологічних знань } \\
3 \text { метою подальших дій } 3 \text { покращення стану } \\
\text { навколишнього середовищ }\end{array}$ & 29,2 \\
\hline Абсолютно не готовий щось робити & 20,8 \\
\hline
\end{tabular}


Як видно з результатів аналізу даного блоку запитань, студенти дійсно готові на активні дії щодо розвитку екологічної культури, підвищення рівню екологічної обізнаності, готові вкладати свої власні зусилля на покращення екологічної ситуації в регіоні. Але є й такі, що скептично налаштовані, вважають, що від них нічного не залежить, тому і робити щось для збереження природи вони абсолютно не готові, таке собі споживацьке та безвідповідальне ставлення. Ці відповіді студентів викликають стурбованість, адже їхня професійна діяльність буде пов'язана із вирішенням проблем клієнтів та пацієнтів, які накопичувались роками і потрібна активна, співчутлива участь у їі вирішенні. Ці факти також наголошують на необхідності впровадження системи інтерактивних технологій для розвитку як когнітивного, так і емоційно-оцінного та поведінкового компонентів екологічної культури студентів.

Важливим фактором формування екологічної компетентності $€$ засвоєння того переконання, що кожен з нас має бути відповідальним за катастрофічні наслідки діяльності у довкіллі, а якщо кожен не візьме на себе цю відповідальність, то він ризикує стати жертвою цих наслідків [1].

Рівень усвідомлення наслідків екологічної діяльності залежатиме від ступеню оволодіння науковими методами прогнозування екологічних наслідків діяльності. Формування цього усвідомлення відбувається через застосування системи безперервної екологічної, еколого-психологічної та екологопедагогічної освіти [11].

Рівень визнання цінності довкілля залежатиме від рівня засвоєння екологічної культури, оскільки екологічна культура передбачає такий спосіб життя, коли суспільство системою духовних цінностей, етичних імперативів, економічних механізмів, правових норм та соціальних інститутів формує потреби і способи їх реалізації не створюють загрозу життя на Землі [12].

В дослідженні було використано методику «Екоціннісні диспозиції» В. О. Скребця [10], яка дозволяє зрозуміти поведінковий компонент екологічної культури. Як зазначає автор, екодиспозиція виступає властивістю особистості, яка спрямовує діяльність, це свого роду фіксовані установки, що формуються поступово шляхом навчально-виховної роботи, і які закріплюються у вигляді звичаїв та схильності оцінювати свою діяльність по відношенню до природи. Сформована екопсихологічна диспозиція передбачає узгодження, підтримку, заохочення, сприяння природі, а ні підпорядкування природи собі, переробку та її покірність людині.

3 розподілу середніх показників прояву екодиспозицій серед досліджуваної вибірки студентів можна помітити, що установка на розуміння того, що потрібно узгоджувати свої наміри, прагнення з закономірностями розвитку природи притаманно лише 51,8 \% студентів, а ця диспозиція, на думку багатьох науковців $є$ більш конструктивною і $є$ проявом достатнього рівню екологічної культури та екологічної свідомості. Споживацьке ставлення до природи, яке є основним змістом несесетивної, совметральної та гашенарної екодиспозицій притаманно
$48,2 \%$ опитаних студентів $(23,8 \%, 15,4 \%$ та $8,9 \%$ відповідно). Байдужість, незацікавленість природою або визнання слабкості перед iї силами, а тому пасивність (індиферентна та совмісійна екодиспозиції) притаманна $32,5 \%$, що також $є$ достатньо високим показником.

Що стосується загальних цінностей, то отримано наступні результати середніх відсоткових значень за вибіркою (рис. 1).

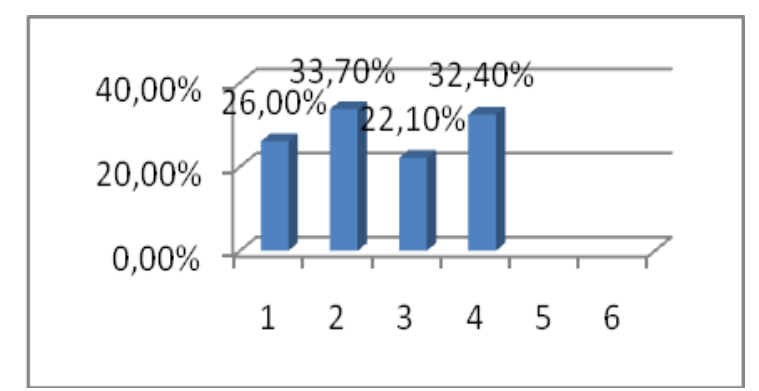

Рисунок 1 - Розподіл середніх відсоткових значень загальних цінностей респондентів:

(1 - соціальні цінності, 2 - екологічні цінності, 3 - моральні цінності, 4 - Я-цінності)

Таким чином, серед респондентів маємо переважання екологічних та Я-цінностей над соціальними та моральними, що викликає позитивне ставлення, тобто, майже третина студентів має розуміння цінності природи та необхідності іï збереження та розумного користування. При цьому Я-цінності (цінності для себе, для задоволення власних інтересів) характерні для 32,4\%. Під цим показником може ховатися і мотив використання природи та іiі ресурсів заради власних потреб, власних бажань, що $є$ деструктивним засобом взаємодії з природою.

ВИСНОВКИ. Отже, дослідження показало недостатній рівень розвитку основних складових екологічної культури студентів, тільки $50 \%$ опитаних мають усвідомлене розуміння важливості природного середовища для сьогодення та майбутнього, розуміння необхідності підвищувати рівень своїх знань, проявляє стурбованість і готові власними діями та зусиллями сприяти покращенню екологічного становища природних ресурсів. При цьому ці студенти мають високий рівень прояву екологічних та моральних цінностей. Інша частина проявляє низький рівень знань, безтурботність, зневажливе ставлення до природних ресурсів та пасивне спостерігання за негативною діяльністю людини стосовно природи та iii захисту. Тому, всі ці аргументи дозволяють зробити наголос на необхідності розробки та впровадження в систему підготовки студентів психологопедагогічних технологій формування складових екологічної культури.

\section{ЛІТЕРАТУРА}

1. Білик Л. І. Екологічна відповідальність : граючись навчаємось. Черкаси : Вертикаль; Кадич С. Г. 2004. 320 c.

2. Дерябо С. Я., Ясвин В. А. Экологическая педагогика и психология. Ростов-на-Дону : Издательство «Феникс», 1996. 480 с. 
3. Захлебный А. Н., Дзятковская Е. Н. Экологическая компетенция - новый планируемый результат экологического образования. Экологическое образование: до школьи, в школе, вне школь. 2007. № 3. C. 3-8.

4. Ясвин В. А. Психолого-педагогическая коррекция субъективного отношения к природе в процессе экологического образования. Вопросы психологии. 1998. № 4. С. 3-13.

5. Попова I. В., Мазур Л. М., Сімурова Н. В., Черепанський В. В. Освітній формування культури екобезпечного розвитку суспільства. Екологічні нау$\kappa u$ № $\quad$ 1(20). $\quad$ T. $2 . \quad$ URL : http://ecoj.dea.kiev.ua/archives/2018/1/part_2/26.pdf (дата звернення 23.02.2019).

6. Симонова И. Н., Варникова О.В.Экологическая культура как феномен современного высшего технического образования. Современные проблемы науки и образования. 2015. №1 (часть первая). URL : https://www.science-

education.ru/ru/article/view?id=17965 (дата звернення 24.02.2019)

7. Льовочкіна А. М. Концептуальний підхід до формування екологічної культури сучасного способу життя. Актуальні проблеми психології. Збірник наукових праць Інституту психології ім. Г. С. Костюка АПН України. За ред. Максименко С. Д. К. : «Логос», 2006. Т. 7. Вип. 7. С. 153-159.

8. Крисаченко В. С. Людина і біосфера: основи екологічної антропології. К. : Заповіт, 1998. 294 с.

9. Максименко О. О. Застосування екологічно орієнтованого тренінгу з метою корекції екологічної свідомості старшокласників. Актуальні проблеми психології. Збірник наукових праць Інституту психологї̈ ім Г. С. Костюка АПН Украӥни. За ред. Максименко С. Д. К. : «Логос», 2006. Т. 7. Вип. 7. С. $166-173$.

10. Скребець В. О., Шлімакова I. І. Екологічна психологія : підручник. К. : Видавничий Дім «Слово», 2014. 456 с.

11. Дідков О. Формування екологічної свідомості та культури засобами освіти та виховання особистості.

URL : http://www.ird.npu.edu.ua/files/didkov.pdf (дата звернення 24.02.2019).

12. Гирусов Э. В. Экологическое сознание как условие оптимизации взаимодействия общества и природы. Философские проблемы глобальной экологии. М. : Наука, 1993. С. 105-120.

\section{PSYCHOLOGICAL AND PEDAGOGICAL BASICS TO DEVELOP THE ENVIRONMENTAL CULTURE OF STUDENTS}

\section{O. Litvinova, O. Bespartochna}

Kremenchuk Mikhailo Ostrogradskyi National University

vul. Pershotravneva 20, Kremenchuk, 39600, Ukraine. E-mail: litvinova1992@gmail.com

Purpose. The purpose of the article is to determine and characterize the psychological and pedagogical basics for forming and developing the ecological and environmental culture of students. Methodology. On researching some theoretical methods are used, including theoretical and systematic analysis of scientific and pedagogical scholarly works, with systematization and generalization of information, as well as Eco-Valued Disposition methodology of V. O. Skrebets which allows understanding the behavioral component of ecological and environmental culture. Results. The research proves the improper level in developing the main components of the students environmental culture, as only $50 \%$ of respondents have a conscious awareness of the natural environment importance for the present and future and essential requirement to improve their knowledge, get anxious and ready to act and contribute to improving the environmental sustainability as to natural resources. Such students have a high level manifestation of environmental and moral values, while others show poor knowledge, carelessness, derogatory attitude to natural resources, and passive observation of the harmful human attitude to the environment and its protection. Originality. The main specific feature of ecological culture is that it does not occur spontaneously, but arises by creating the conditions conducive to the development of its principles and providing the environmental education as a special kind of activity. Solving the problem of the global ecological crisis and preserving the natural conditions for the civilization existence depends on the level of mankind ecological culture, first of all the young as a future generation. The article provides the arguments emphasizing the value to develop and implement the psychological and pedagogical techniques to form the components of ecological culture in system of higher education process. Practical value. The facts of our study emphasize the need to implement a system of interactive techniques for developing both the cognitive, emotional, behavioral and evaluative components of the students' environmental culture. Findings. Recognition of our responsibility for the catastrophic consequences of human activities for the environmental is a significant factor in developing the environmental competence.

Key words: environmental culture, values, ecological awareness, student age, eco-valued disposition, environmentally-oriented training.

\section{REFERENCES}

1. Bilyk, L. I. (2004), “Ekolohichna vidpovidalnist: hraiuchys navchaiemos" [Environmental responsibility: learn playing], Vertykal Publishing house, Kandych S. $\mathrm{H}$, Cherkasy, Ukraine.

2. Deriabo, S. Ya., Yasvin, V. A. (1996), "Ekolohicheskaia pedahohika i psikholohiia" [Environmental pedagogy and psychology], Feniks Publishers, Rostovna-Donu, Russia.
3. Zakhliebnyi, A. N., Dziatkovskaia, E. N. (2007), "Ekolohicheskaia kompetentsiia - novyi planiruemyi rezultat ekolohicheskoho obrazovaniia" [Environmental competence - a new planned result of environmental education], Ekolohicheskoe obrazovanie: do shkoly, $v$ shkole, vne shkoly [Environmental education: before school, at school, outside school], No 3, pp. 3-8. 
4. Iasvin, V. A. (1998), "Psykholoho-pedahohicheskaia korrektsiia subiektivnoho otnosheniia $k$ prirode $v$ protsesse ekolohicheskoho obrazovaniia" [Psychological and pedagogical correction of the subjective attitude to nature in the process of environmental education], Voprosy psikholohii [Psychology issues], No 4, pp. 3-13.

5. Popova, I. V., Mazur, L. M., Simurova, N. V., Cherepanskyi, V. V. "Osvitnii formuvannia kultury ekobezpechnoho rozvytku suspilstva" [Educational formation of a culture of environmentally sustainable development of society], URL: http://ecoj.dea.kiev.ua/archives/2018/1/part_2/26.pdf.

6. Simonova, I. N., Varnikova, O. V. "Ekolohicheskaia kultura kak fenomen sovremennoho vyssheho tekhnicheskoho obrazovaniia" [Ecological culture as a phenomenon of modern higher technical education], URL: education.ru/ru/article/view?id=17965.

7. Lovochkina, A. M. (2006), “Kontseptualnyi pidkhid do formuvannia ekolohichnoi kultury suchasnoho sposobu zhyttia" [Conceptual approach to the formation of the ecological culture of modern lifestyle], Aktualni problemy psykholohii, Zbirnyk naukovykh prats Instytutu psykholohii im H. S. Kostiuka APN Ukrainy [Actual problems of psychology, Collection of scientific works of G. S. Kostyuk Institute of Psychology of the Academy of Pedagogical Sciences of Ukraine], edited by Maksimenko S. D., Kyiv: Lohos Publishers, 2006, No 7, pp. 153-159.
8. Krysachenko, V. S. (1998), Liudyna i biosfera: osnovy ekolohichnoi antropolohii [Man and Biosphere: Fundamentals of Environmental Anthropology], Zapovit Publishers, Kyiv, Ukraine.

9. Maksymenko, O. O. (2006), “Zastosuvannia ekolohichno oriientovanoho treninhu z metoiu korektsii ekolohichnoi svidomosti starshoklasnykiv" [Application of ecologically oriented training for correction of ecological consciousness of senior pupils], Aktualni problemy psykholohii, Zbirnyk naukovykh prats Instytutu psykholohii im H. S. Kostiuka APN Ukrainy [Actual problems of psychology, Collection of scientific works of G. S. Kostyuk Institute of Psychology of the Academy of Pedagogical Sciences of Ukraine], edited by Maksimenko S. D., Kyiv: Lohos Publishers, 2006, No 7, pp. 166-173.

10. Skrebets, V. O., Shlimakova, I. I. (2014), "Ekolohichna psykholohiia: pidruchnyk" [Ecological Psychology: Textbook], Slovo Publishing House, Kyiv, Ukraine.

11. Didkov, O. Formuvannia ekolohichnoi svidomosti ta kultury zasobamy osvity ta vykhovannia osobystosti [Formation of ecological consciousness and culture by means of education and personality upbringing], URL:http://www.ird.npu.edu.ua/files/didkov.pdf.

12. Hirusov, E. V. (1983), "Ekolohicheskoe soznanie kak uslovie optimizatsii vzaimodeistviia obshchestva i prirody" [Ecological consciousness as a condition for optimizing the interaction of society and nature], Filosofskie problemy hlobalnoi ekolohii [Philosophical problems of global ecology], Nauka Publishers, Moskow, Russia, pp. 105-120.

Стаття надійшла 25.03.2019.. 